\title{
Evaluation of biopsy systems for sampling white shark Carcharodon carcharias (Lamniformes: Lamnidae) muscle for stable isotope analysis
}

\author{
Evaluación de métodos de colecta de músculo de tiburón blanco Carcharodon carcharias \\ (Lamniformes: Lamnidae) para análisis de isótopos estables \\ Mario Jaime-Rivera ${ }^{1}$, Javier Caraveo-Patiño ${ }^{1}$, Mauricio Hoyos-Padilla ${ }^{2}$ \\ and Felipe Galván-Magaña ${ }^{3}$
}

\begin{abstract}
${ }^{1}$ Centro de Investigaciones Biológicas del Noroeste, Instituto Politécnico Nacional No. 195, 6 Col. Playa Palo de Santa Rita Sur, La Paz, B.C.S. 23096, México. jcaraveo04@cibnor.mx

${ }^{2}$ Pelagios-Kakunjá, Sinaloa 1540, La Paz, B.C.S., México

${ }^{3}$ Centro Interdisciplinario de Ciencias Marinas, Av. Instituto Politécnico Nacional s/n, Col. Playa Palo de Santa Rita, La Paz, B.C.S. 23096, México
\end{abstract}

Resumen.- Los métodos manuales para la obtención de biopsias de tiburones que nadan libremente han tenido tasas de éxito limitadas para diferentes tipos de tejidos. El músculo es un tejido importante, sin embargo muchos métodos fallan en recolectarlo y sólo obtienen dermis. Se describe el uso de 3 diferentes sistemas de dardos para la obtención de biopsias y se evaluó la tasa de éxito en la recolecta de músculo de tiburón blanco en Isla Guadalupe, México. Los resultados sugieren que el sistema de Reeb \& Best (dardo RB) fue el mejor para obtener tejido muscular debido a que el grosor de la dermis del tiburón blanco es $\sim 1,0 \mathrm{~cm}$. El análisis de isótopos estables entre los diferentes tejidos (dermis y músculo) sugiere una diferente tasa de recambio. No hubo diferencia significativa entre los valores isotópicos de las regiones profunda y superficial del músculo. Una biopsia de 5,0 cm de longitud podría ser suficiente para obtener músculo para realizar análisis de isótopos estables u otros.

Palabras clave: Tiburón blanco, métodos para obtención de biopsias, señales isotópicas de carbono y nitrógeno, músculo

\begin{abstract}
Manual biopsy methods are typically used to obtain samples from free-swimming sharks but have had limited or varied success rates for different types of tissues. Muscle is the tissue desired when biopsies are used, however many methods fail to collect muscle and only collect dermis. The use of 3 different dart systems was described for manual biopsies and the success rate and tissue yield from white sharks at Isla Guadalupe, México was evaluated. Results suggest that the Reeb \& Best biopsy system (RB dart) was best to biopsy muscle tissue because this dart was able to penetrate the dermal layer of white sharks is $\sim 1.0 \mathrm{~cm}$. Stable isotope analysis revealed no significant difference between outer and deeper muscle regions. A biopsy of $5.0 \mathrm{~cm}$ or less would be sufficient to obtain enough muscle for stable isotope and other kinds of analysis.
\end{abstract}

Key words: White shark, biopsy methods, isotopic signatures of carbon and nitrogen, muscle

\section{INTRODUCTION}

In recent years some shark species have become protected, requiring the development of new non-lethal techniques to collect tissue samples. White sharks are listed as vulnerable by the International Union for Conservation of Nature (IUCN) and protected under the Convention on the International Trade in Endangered Wild Flora and Fauna (Dulvy et al. 2008). New minimally invasive sampling methods have been developed to study shark ecology. Remote tissue sampling techniques using darts provides an alternative to sacrificing animals or relying on naturally deceased animals for tissue samples. This method reduces mortality and is attractive for working with endangered species (Baker et al. 2004).

Shark skin consists of an outer epidermis followed by dermis. The epidermis consists of dermal denticles and the dermis is made up of elastic fibers composed of elastine and collagen. The dermis is thicker in the anterior region than in the posterior region (Motta 1977, Naresh et al. 1997). The width of the dermal layer is variable between species. It is generally assumed that in larger sharks the dermal layer is thicker than in smaller sharks (Motta 1977), complicating the sampling of muscle tissue of sharks in larger developmental stages or large species. 
Difficulty in sampling white sharks has lead to a gap within the literature/research. Manual methods to obtain samples from free-swimming sharks are commonly used. Spears or harpoons with stainless steel darts are employed which permit only the collection of small portions of dermal skin. For example, steel darts of $5 \mathrm{~cm}$ in length with flatten tips have been used to obtain dermal samples of whale sharks (Ramírez et al. 2007) and steel tips have been used to obtain samples of free swimming bull sharks (Daly \& Smale 2013).

Stable isotope analysis (SIA) provides information about assimilated food, prey preferences, intrinsic tissue signatures for different locations, tissue turnover, migration patterns and food web interactions (Gannes et al. 1997, Schell et al. 1998, Hobson \& Sease 1998, Lesage et al. 2001). The dietary information retained in the tissues of predators depends upon the elemental turnover rates, the isotopic composition of each food web, and the prey items in the diet (Tieszen et al. 1983). White shark Carcharodon carcharias (Linnaeus, 1758), stable isotope data is scarce (Kerr et al. 2006, Estrada et al. 2006, Carlisle et al. 2012, Hussey et al. 2012).
From 2007 to 2011 different sampling techniques were tested to obtain white shark muscle at Isla Guadalupe. Fifty one samples of white shark tissues were obtained in order to find differences of isotopic signatures between dermis and muscle. The main aim of this study was to evaluate the efficacy and sample yield of three different biopsy systems and to further investigate if a difference exists between the stable isotope compositions of different tissues in white sharks.

\section{MATERIALS AND METHODS}

\section{BIOPSY TECHNIQUE}

In situ manual biopsies were taken with a harpoon and pole with stainless steel darts attached. Sharks were attracted with tuna bait, a technique termed chumming. We sterilized the darts with fire to prevent bacterial contamination. Samples were taken behind the first dorsal fin to avoid harming the specimens. All sharks were photoidentified from an underwater cage. Three different types and sizes of darts were tested.

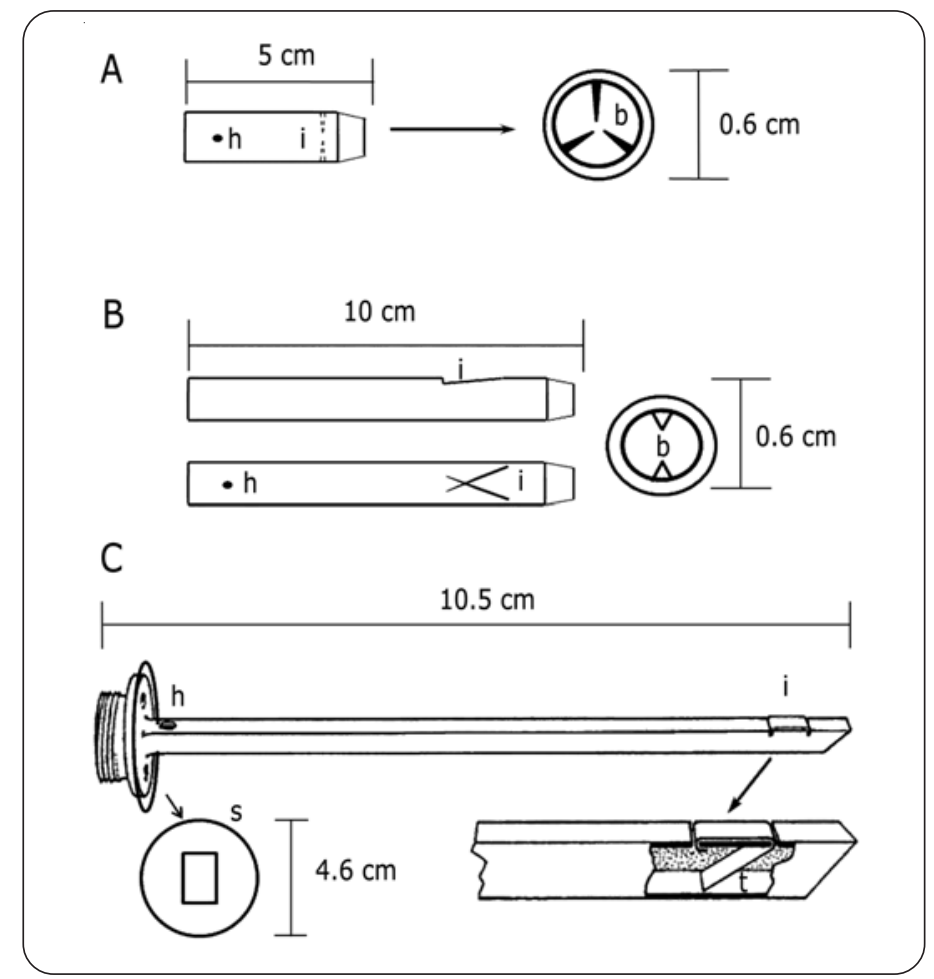

Figure 1. Diagrams of steel darts used to obtain white shark biopsies. A) Dart 1; B) Dart 2 and C) RB dart. h: hole for water outflow; b: retention barbs; t: trap-door; i: incisions for retention barbs; s: stopper / Diagramas de los dardos de acero utilizados para colectar biopsias de tiburón blanco. A) Dardo 1; B) Dardo 2 y C) Dardo RB. h: orificio para el flujo de agua; b: ganchos de retención; t: puerta de corte, i: incisiones para los ganchos de retención; s: tope 
Dart 1: Steel dart measuring $5 \mathrm{~cm}$ in length and $0.6 \mathrm{~cm}$ in diameter with tapered edges based on a cutting head originally designed by Winn et al. (1973). These tips have 3 retention barbs affixed internally to assure sample retention and a single vent hole to allow water pressure to escape during impact (Fig.1A). This dart was the smallest dart tested.

Dart 2: The second dart tested has an elongated steel cutting head measuring $10 \mathrm{~cm}$ in length and $0.6 \mathrm{~cm}$ in diameter. A retention barb in the form of an $\mathrm{X}$ is oriented along the longitudinal axis of the cylinder and functions to hold the sample in place (Fig. 1B).

Dart 3: The RB dart is a rectangular shaped dart based on Reeb \& Best's biopsy system (Reeb \& Best 2006) which was designed to collect deep core blubber samples of Southern Right Whale calves Eubalaena australis. This steel dart measured $10.5 \mathrm{~cm} \times 0.8 \mathrm{~cm} \times 0.4 \mathrm{~cm}$ in length, breadth and height $(\mathrm{l} / \mathrm{b} / \mathrm{h})$. This dart has a hard plastic stopper at the end to halt penetration at $4.6 \mathrm{~cm}$ in diameter diameter and at $0.02 \mathrm{~cm}$ thickness (Fig. 1C).

Male and female animals of different sizes were sampled in order to evaluate if the depth of the dermal layer is different between sexes and size classes. Dermis success rate (DSR) and muscle success rate (MSR) is defined as the percentage of events when tissues of sharks were obtained in each sampling attempt. Once the sample was obtained, tissue samples were placed on a ruler to measure length. Non-parametric Wilcoxon rank sums-test (Wilcoxon 1945) was used to detect differences. A regression analysis was conducted to find a feasible relation between size and the dermal layer thickness.

\section{STABLE ISOTOPE ANALYSIS}

We divided the muscle tissue obtained by the third punch into 2 different sections, near the dermis (outer) and deeper (> $2 \mathrm{~cm}$ depth) in order to evaluate if the isotopic signature was different between them. Prior to analysis, the shark tissues were thawed in seawater and a small section of

Table 1. Success rate of sampling / Éxito del rango de muestreo

\begin{tabular}{cccccc}
\hline & $\begin{array}{c}\text { N } \text { of } \\
\text { attempts }\end{array}$ & $\begin{array}{c}\text { No of biopsies No of muscle } \\
\text { collected }\end{array}$ & $\begin{array}{c}\text { DSM } \\
\text { collected }\end{array}$ & $\begin{array}{c}\text { MSR } \\
(\%)\end{array}$ \\
\hline Dart 1 & 19 & 15 & 0 & 80 & 0 \\
Dart 2 & 17 & 16 & 3 & 95 & 17 \\
RB dart & 20 & 20 & 19 & 100 & 95 \\
\hline
\end{tabular}

white muscle ( $1 \mathrm{~g}$ ) was excised from just below the skin and connective tissue. Muscle samples were rinsed with distilled water to remove any excess superficial debris. Samples were rinsed with deionized water to remove urea. Each rinse consisted of $10 \mathrm{ml}$ of solution at 1500 psi for 5 min. The lipids were removed by rinsing the ground tissue several times with 2:1 chloroform: methanol mixture, following the method of Folch et al. (1957). The muscle sections were dried for $3 \mathrm{~d}$ at $70^{\circ} \mathrm{C}$; then ground with a mortar and pestle.

Samples were put in flasks with Teflon caps and lyophilized. Subsamples of $\sim 0.001 \mathrm{~g}$ were encapsulated in tin capsules $(8 \mathrm{~mm} \times 5 \mathrm{~mm})$. Isotope values of carbon (C) and nitrogen (N) were obtained by mass spectrometry at the Continuous Flow-Isotope Ratio Mass Spectrometry Laboratory at the University of California, Santa Cruz. Isotope signatures were reported as delta values $(-\delta \mathrm{X})$, where $X$ is the heavy isotope with reference to the standard, expressed as parts per thousand (\%o). These data were calculated according to the formula:

$$
\delta \mathrm{X}=(\mathrm{R} \text { sample } / \mathrm{R} \text { standard }-1) \times 1000 \text {, }
$$

where, $\mathrm{R}$ sample is the ratio between the heavy isotope and the light isotope of the sample and R standard is the ratio between the heavy isotope and the light isotope of a standard for the isotopes. The standard for $\mathrm{d}^{13} \mathrm{C}$ was carbon dioxide from calcium carbonate produced by the Cretaceous belemnoid fossil Belemnitella americana (PDB, Pee Dee Belemnite). The standard for $\mathrm{d}^{15} \mathrm{~N}$ was atmospheric nitrogen. A non-parametric Wilcoxon rank sums-test (Wilcoxon 1945) was used to detect isotopic differences between dermis and muscle.

\section{Results}

\section{SuCCESS RATE}

Dart one was tested from August to November 2007-2009. We obtained 15 white shark biopsy samples with $80 \%$ DSR, and 0\% MSR. The average biopsy sample size was $0.8 \mathrm{~cm}$ of tissue. Dart 2 was tested from September to December 2010 and 16 white shark biopsy samples were obtained with a sampling success rate of 95\% DSR and $17 \%$ MSR. The average biopsy sample size was $1 \mathrm{~cm}$ of tissue predominantly dermis. Dart 3, the RB dart obtained 20 biopsies from September to October 2011. The success rate of the RB dart for obtaining samples was 100\% DSR and the success rate for obtaining muscle was 95\% MSR (Table 1 ). With the last technique 10 males and 10 females were sampled ranging from $2.5 \mathrm{~m}$ to $5 \mathrm{~m}$ total length. From 
Table 2. White shark biopsy measurements taken by the RB dart / Biopsias de tiburón blanco obtenidas por el dardo RB

\begin{tabular}{|c|c|c|c|c|}
\hline Sex & $\begin{array}{l}\text { Size } \\
(\mathrm{m})\end{array}$ & $\begin{array}{l}\text { Biopsy } \\
\text { length } \\
\text { (cm) }\end{array}$ & $\begin{array}{l}\text { Thickness } \\
\text { of dermal } \\
\text { layer }(\mathrm{cm})\end{array}$ & $\begin{array}{c}\text { Muscle } \\
\text { length } \\
\text { (cm) }\end{array}$ \\
\hline $\mathrm{F}$ & 4 & 2.4 & 1 & 1.4 \\
\hline $\mathrm{F}$ & 3 & 3.8 & 1 & 2.8 \\
\hline $\mathrm{F}$ & - & 1.4 & 1 & 0.4 \\
\hline $\mathrm{F}$ & 4 & 5.4 & 1 & 4.4 \\
\hline $\mathrm{F}$ & 4.5 & 1.9 & 1 & 0.9 \\
\hline $\mathrm{M}$ & 4.5 & 4.5 & 1 & 3.5 \\
\hline $\mathrm{M}$ & 4.5 & 2 & 1 & 1 \\
\hline $\mathrm{M}$ & 3 & 4 & 1 & 3 \\
\hline $\mathrm{M}$ & - & 3.5 & 1.5 & 2 \\
\hline $\mathrm{M}$ & 3 & 8.8 & 1 & 7.8 \\
\hline $\mathrm{M}$ & 4 & 3.5 & 1 & 2.5 \\
\hline $\mathrm{F}$ & 3.5 & 6.3 & 1 & 5.3 \\
\hline $\mathrm{F}$ & 3 & 4.2 & 1 & 3.2 \\
\hline $\mathrm{F}$ & 5 & 3 & 3 & - \\
\hline $\mathrm{F}$ & 5.5 & 2 & 1.8 & 0.2 \\
\hline $\mathrm{M}$ & 3.5 & 2 & 0.5 & 1.5 \\
\hline $\mathrm{F}$ & 4.5 & 5.9 & 1.9 & 4 \\
\hline $\mathrm{M}$ & 3 & 1.9 & 1 & 0.9 \\
\hline $\mathrm{M}$ & 3 & 2.4 & 0.6 & 1.8 \\
\hline $\mathrm{M}$ & 2.5 & 1 & 0.7 & 0.3 \\
\hline
\end{tabular}

the 20 samples, 19 muscle tissues were obtained. The shortest sample was $1 \mathrm{~cm}$ and the largest was $8.8 \mathrm{~cm}$. Size sample average was $3.5 \mathrm{~cm}$ total tissue. Size sample average for dermis was $1.1 \mathrm{~cm}$ and size sample average for muscle tissue was $2.4 \mathrm{~cm}$. Only 4 samples had a size $>$ $1.0 \mathrm{~cm}$ of dermal layer and 3 samples were $<1.0 \mathrm{~cm}$ of dermal layer (Table 2). There was no relation between width of the dermal layer and the length of the muscle obtained. The largest muscle was $7.8 \mathrm{~cm}$ corresponding to the longest biopsy sampled. We sampled one biopsy with a dermal layer of $3 \mathrm{~cm}$ without muscle. During the study we observed that the overall reactions of the sharks to the RB dart were no greater than to the more superficial sampling using the 2 other darts. The reactions were: no response, startling and tail slapping. However, when comparing the RB dart to the other dart systems, this dart caused an evident hemorrhagic response in the sampled white sharks.

There was no difference between the sex of the sharks (10 males and 10 females) and the length of the dermal layer $\left(\chi^{2}=2.628\right.$, d.f. $\left.=1, P>0.05, \chi^{2}=0.1050\right)$. There was no relation between the size of the sharks and the length of the biopsy ( $r=0.112, P=0.656)$. However, a significant positive correlation was found between the size of the sharks and the thickness of the dermal layer ( $r=0.633, P$ $=0.004)$. This data analysis was only performed on the RB dart data (Fig. 2).

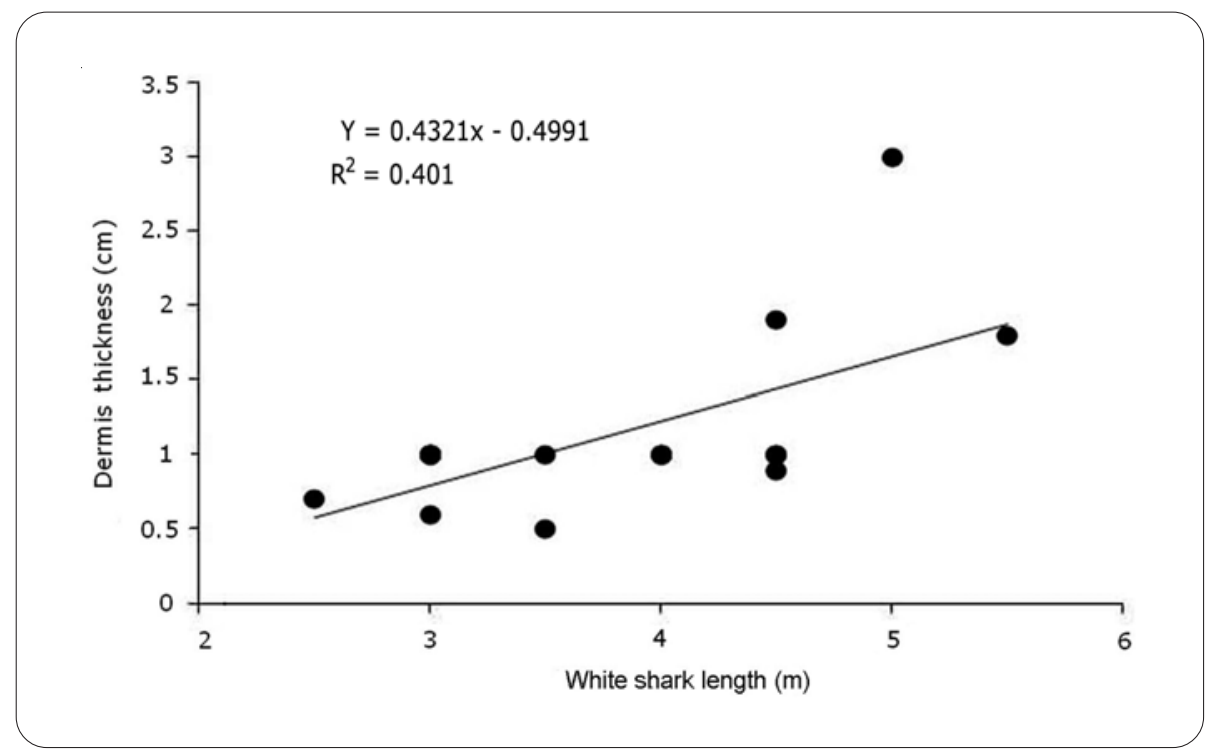

Figure 2. Relationship between the size and the thickness of the dermal layer of the white sharks / Relación entre la talla y el grosor de la dermis de los tiburones blancos 


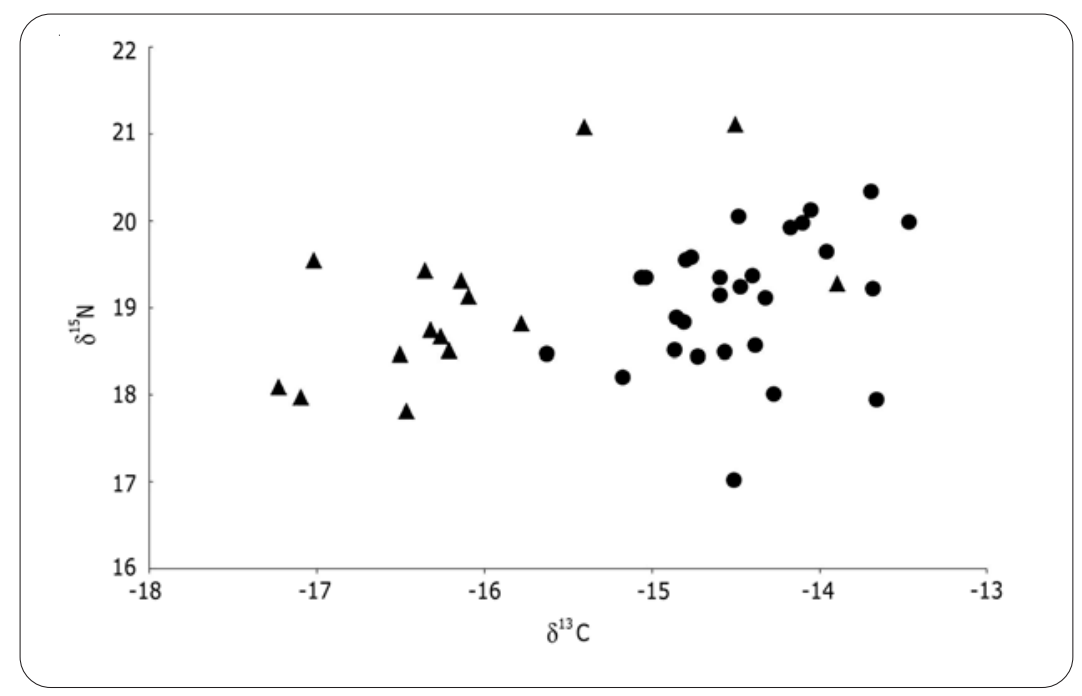

Figure 3. Isotopic values of dermis (circles) and muscle (triangles) / Valores isotópicos de dermis (círculos) y músculo (triángulos)

Of the 3 darts tested, the RB dart was by far the best at obtaining muscle samples (95\% of biopsies collected muscle). The second best was Dart 2 (17\% MSR) and Dart 1 never obtained muscle. In 2010, we elongated the tip length to $10 \mathrm{~cm}$ in order to obtain muscle, because we thought that the dermal layer was the main obstacle in reaching it, but we had limited success.

\section{STABLE ISOTOPE ANALYSIS}

The average isotope signature for dermal tissue was -4.4 $\pm 0.5 \%$ o $\left(\mathrm{n}=28\right.$, mean \pm SD) for $\delta^{13} \mathrm{C}$ and $19.1 \pm 0.7 \%$ o $(\mathrm{n}=$ 28 , mean $\pm \mathrm{SD}$ ) for $\delta^{15} \mathrm{~N}$. For the muscle outer region the average isotope signature was $-17.4 \pm 0.7 \%$ ( $\mathrm{n}=14$, mean $\pm \mathrm{SD})$ for $\delta^{13} \mathrm{C}$ and $15.8 \pm 1.0 \%$ o $(\mathrm{n}=14$, mean \pm SD) for $\delta^{15} \mathrm{~N}$. For the muscle deeper region the average isotope signature was $-17.6 \pm 0.4 \%$ o $\left(n=9\right.$, mean \pm SD) for $\delta^{13} \mathrm{C}$ and $15.6 \pm 0.9 \%$ o $\left(n=9\right.$, mean \pm SD) for $\delta^{15} \mathrm{~N}$ (Fig. 3). There was no significant differences in isotope signatures between the outer and deeper region for $\delta^{13} \mathrm{C}$ (ANOVA, $\left.\mathrm{F}_{(1,21)}=0.9, P=0.34\right)$ and for $\delta^{15} \mathrm{~N}\left(\right.$ ANOVA, $\mathrm{F}_{(1,21)}=0.07$, $P=0.79)$.

There was significant differences in isotope signatures between dermis and muscle for $\delta^{13} \mathrm{C}$ (ANOVA, $\mathrm{F}_{4.091}=59.9$, $P<0.05$ ). Wilcoxon $\mathrm{Z}=3.1 P<0.05$ (Fig. 4) but there was no significant differences in isotope signatures between dermis and muscle for $\delta^{13} \mathrm{~N}$ (ANOVA, $F_{4.078}=0.01, P>$ 0.05).

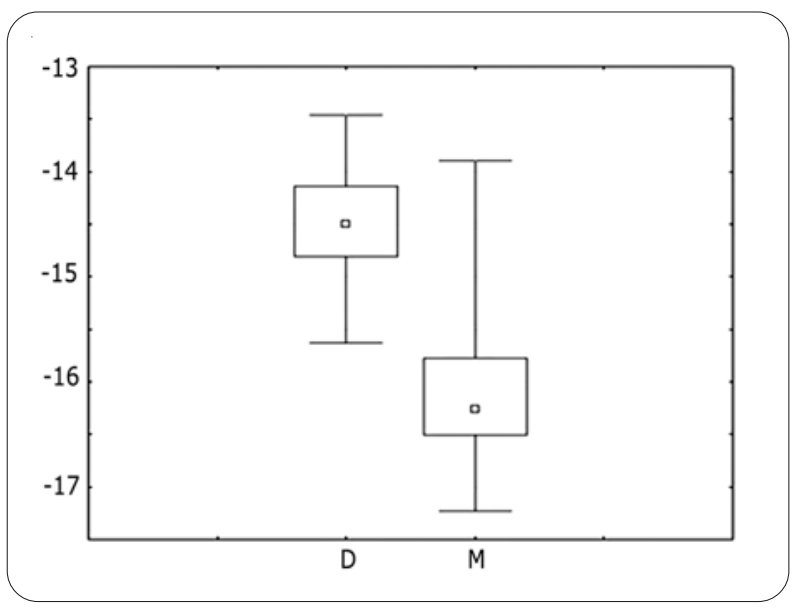

Figure 4. Significant differences in isotope signatures between dermis (D) and muscle (M) for $\delta^{13} \mathrm{C} /$ Diferencia significativa para el $\delta^{13} C$ entre la dermis (D) y el músculo (M)

\section{Discussion}

Reeb \& Best (2006) reported that the average length of the samples they obtained did not fill the entire length of the punch or dart. The success for obtaining muscle depends more on the retention barb design rather than the length of the dart. The barb system of conventional darts was originally designed to collect blubber samples of marine mammals; hence a soft tissue like white shark muscle cannot be retained properly by these. When we used the RB dart which uses a trap-door design instead 
of barbs, we obtained muscle and observed that the width of the dermis was very similar between biopsies, suggesting that the way that the dart cuts the tissue was the key to success. The trap-door design cuts the muscle tissue longitudinally, and then closes allowing for the tissue to be retained.

Our results confirm that the dermal layer is thicker in large sharks such as the white shark compared to smaller sharks (e.g., Rhizoprionodon terraenovae, Ginglymostoma cirratum, Sphyrna lewini and Mustelus canis ranged between $0.2 \mathrm{~mm}$ and $1.6 \mathrm{~mm}$ ) (Motta 1977). However, variation in dermal layer thickness was low between individuals (white shark $1.0 \mathrm{~cm}$, Table 1 ). Even though a cutting head of $10.5 \mathrm{~cm}$ was used, our results indicate that a $5 \mathrm{~cm}$ cutting head would be sufficient to obtain muscle. Moreover, our results suggest that the retention barbs dart system cuts muscle but fails to retain it once the dart is retrieved from the animal. As there was no relation between shark size and the length of the biopsy in the RB dart, the length of the biopsy obtained depended upon the extreme angle of the pole when the shark was struck. At extreme angles the biopsy penetrated parallel the surface of the skin, thereby never penetrating through the dermis and collecting muscle. Hence why one sample with $3 \mathrm{~cm}$ of dermal layer and no muscle was obtained (Table 1).

Statistically, the correlation between the size of the shark and the thickness of the dermal layer imply that larger white sharks have a thicker dermal layer, but this result is also influenced by the smaller number of white sharks sampled and the angle of the pole when it strikes the sharks. A greater sample size of sharks could corroborate this assumption and emphasize the usefulness of the RB dart in studying the thickness of the dermal layer of large sharks.

The length of the muscle biopsies was variable; also the lengths of samples did not completely fill the cavity of the dart supplied. This is in agreement with what was reported by Reeb \& Best (2006) where they also found variation of biopsy size. They suggested that this is caused by the failure of the barb to close before some of the sample has already been withdrawn or cut from the punch. The reactions of the sharks to the $\mathrm{RB}$ dart were similar with those recorded when using the first 2 barbtype darts, but when muscle was obtained there was an evident hemorrhagic response in all the sampled sharks. At the moment of sampling, the bleeding is the only evidence that muscle tissue was reached. If hemorrhaging is observed but the punch or dart does not collect muscle, it implies that the dart is failing and should be replaced. Further experimentation is required to understand how this bleeding can affect the sharks or whether it can possibly trigger a frenzy or similar behaviors.

Our muscle isotopic values of white sharks sampled near Guadalupe Island are similar to those sampled near the Coast of California (Carlisle et al. 2012). This implies that their trophic dynamics are alike in the Northeast Pacific. White sharks from Guadalupe Island and Central California appear to have similar spatial and temporal behavior patterns; they migrate to the same oceanic regions during the same seasons and concentrate near pinnipeds colonies (Domeier \& Nasby-Lucas 2008).

Muscle isotopic signatures show that muscle may have a different turnover rate than dermis. White-muscle tissue is viewed as a long-term integrated measure of elasmobranchs feeding habits and environment. Structural components with low rates of protein turnover, such as collagen and striated muscle will have lower rates of isotopic incorporation than splanchnic organs (Martínez del Rio et al. 2009, Kim et al. 2011). Some studies suggest that dermal collagen could have a higher incorporation rate than muscle (Carlisle et al. 2012). This is speculative, stable isotope dynamics for dermis has not been described for elasmobranchs. Difference between dermal and muscle signatures may be due to the isotopic routing (Gannez et al. 1997) or differences in amino acid composition (Carlisle et al. 2012).

Results suggest that even though we used the RB dart $10.5 \mathrm{~cm}$ in length, a shorter punch (possibly of $5.0 \mathrm{~cm}$ or shorter) would work in extracting muscle tissue of white shark, since it was found that its dermal layer is $\sim 1.0 \mathrm{~cm}$. Moreover, for the third dart there was no significant difference in stable isotope data between the outer and the deeper region of the muscle. A shorter punch also would reduce the hemorrhage incurred to the shark. This sampling method opens the opportunity to use the muscle of large sharks to improve eco-physiological studies, investigating population ecology or veterinary medicine.

\section{ACKNOWLeDGMenTs}

Funding was provided by the World Wildlife Fund, PROMEXICO, project 'Movements of white sharks in Guadalupe Island' (Project KZ85), Instituto Politécnico Nacional (COFAA, EDI), Centro de Investigaciones Biológicas del Noroeste (CIBNOR) and CONACYT. Special thanks to Guillermo García-Cortés and Jorge Cobos-Anaya for the manufacture of the darts. 


\section{LITERATURE CITED}

Baker RF, PJ Blanchfield, MJ Paterson, RJ Flett \& L Wesson. 2004. Evaluation of nonlethal methods for the analysis of mercury in fish tissue. Transaction of the American Fisheries Society 133: 568-576.

Carlisle AB, SL Kim, BX Semmens, DJ Madigan, SJ Jorgensen, CR Perle, SD Anderson, TK Chapple, PE Kanive \& BA Block. 2012. Using stable isotope analysis to understand the migration and trophic ecology of Northeastern Pacific white sharks (Carcharodon carcharias). PLoS ONE 7(2): e30492. <doi:10.1371/ journal.pone.0030492>

Daly R \& MJ Smale. 2013. Evaluation of an underwater biopsy probe for collecting tissue samples from bull sharks Carcharhinus leucas. African Journal of Marine Science 35(1): 129-132.

Domeier M \& N Nasby-Lucas. 2008. Migration patterns of white sharks Carcharodon carcharias tagged Guadalupe Island, Mexico, and identification of an eastern Pacific shared offshore foraging area. Marine Ecology Progress Series 370: 221-237.

Dulvy NK, JK Baum, S Clarke, LJVCompagno, E Cortés, A Domingo \& S Fordham. 2008. You can swim but you can't hide: the global status and conservation of oceanic pelagic sharks and rays. Aquatic Conservation Marine and Freshwater Ecosystems 18: 459-482.

Estrada JA, AN Rice, LJ Natanson \& GB Skomal. 2006. Use of isotopic analysis of vertebrae in reconstructing ontogenetic feeding ecology in white sharks. Ecology 87: 829-834.

Folch J, M Lees \& GH Stanley. 1957. A simple method for the isolation and purication of total lipids from animal tissues. Journal of Biological Chemistry 226: 497-509.

Gannes LZ, DM O’Brien \& CM del Rio. 1997. Stable isotopes in animal ecology: assumptions, caveats, and a call for more laboratory experiments. Ecology 78: 12711276.

Hobson KA \& JL Sease. 1998. Stable isotope analyses of tooth annuli reveal temporal dietary records: an example using Steller sea lions. Marine Mammal Science 14: 116129.

Hussey NE, SFJ Dudley, ID McCarthy, C Geremy \& AT Fisk. 2012. Stable isotope profiles of large marine predators: viable indicators of trophic position, diet, and movement in sharks. Canadian Journal of Fisheries and Aquatic Science 68: 2029-2045.
Kerr LA, AH Andrews, GM Cailliet, TA Brown \& KH Coale. 2006. Investigations of $\Delta^{14} \mathrm{C}, \delta^{13} \mathrm{C}$, and $\delta^{15} \mathrm{~N}$ in vertebrae of white shark (Carcharodon carcharias) from the eastern North Pacific. Environmental Biology of Fishes 77: 337353.

Kim SL, DR Casper, F Galván-Magaña, R Ochoa-Díaz, SB Hernández-Aguilar \& PL Koch. 2011. Carbon and nitrogen discrimination factors for elasmobranch soft tissues based on a long-term controlled feeding study. Environmental Biology of Fishes 95(1): 37-52. < doi 10.1007/s10641-10011-19919-10647>

Lesage V, MO Hammill \& KM Kovacs. 2001. Marine mammals and the community structure of the estuary and Gulf of St Lawrence, Canada: evidence from stable isotope analysis. Marine Ecology Progress Series 210: 203-221.

Martínez del Rio C, N Wolf, SA Carleton \& LZ Gannes. 2009. Isotopic ecology ten years after a call for more laboratory experiments. Biological Reviews 84: 91-111.

Motta ÑJ. 1977. Anatomy and functional morphology of dermal collagen fibres in shark. Copeia 3: 454-464.

Naresh MD, V Arumugam \& R Sanjeevi. 1997. Mechanical behaviour of shark skin. Journal of Biosciences 22(4): 431437.

Ramírez-Macías D, R Vázquez-Juárez, F Galván-Magaña \& A Munguía-Vega. 2007. Variations of the mitochondrial control region sequence in whale sharks (Rhincodon typus) from the Gulf of California, Mexico. Fisheries Research 84: 87-95.

Reeb D \& PB Best. 2006. A biopsy system for deep- core sampling of the blubber of southern right whales Eubalaena australis. Marine Mammal Science 22: 206-213.

Schell DM, BA Barnett \& KA Vinette. 1998. Carbon and nitrogen isotope ratios in zooplankton of the Bering, Chukchi and Beaufort seas. Marine Ecology Progress Series 162: $11-23$

Tieszen LL, TW Boutton, KG Tesdahl \& NA Slade. 1983. Fractionation and turnover of stable carbon isotopes in animal tissues: Implications for $\delta^{13} \mathrm{C}$ analysis of diet. Oecologia 57: 32-37.

Wilcoxon F. 1945. Individual comparisons by ranking methods. Biometrics Bulletin 1: 80-83.

Winn HE, WL Bishoff \& AG Tarusky. 1973. Cytological sexing of Cetacea. Marine Biology 23: 343-346. 